\title{
IN QUEST OF UNIVERSAL GOALS: ANALYSIS OF STATEMENTS FROM THE OPEN WORKING GROUP ON SUSTAINABLE DEVELOPMENT GOALS AND THE UNITED NATIONS GENERAL ASSEMBLY VOTING
}

\author{
Denis Degterev*
}

On 25 September 2015, during the $70^{\text {th }}$ anniversary session of the United Nations General Assembly, the 193 Member States adopted a comprehensive and ambitious set of development goals aimed at the eradication of poverty in all its forms. The present article analyses the consultative process of the Sustainable Development Goals, as well as the positions of countries in negotiations, divided into two groups: donor countries and recipient countries. As to the consultative process, a detailed analysis of the main groups is submitted, along with the institutional design of the process. In addition, a comprehensive review of the countries' positions in the Open Working Group (OWG) on Sustainable Development Goals, which includes a comparative analysis of the donor country statements (traditional, BRICS (Brazil, Russian Federation, India, China and South Africa) and Arabic donors) and statements from recipient countries (by region) is presented. The position of the Russian Federation as a donor country is particularly noted. This position along with that of other BRICS countries is closer to position held by recipient countries, namely the Global South position. An analysis of the G20 countries' annual voting on the United Nations General Assembly resolution 41/128: Declaration on the Right to Development is also provided. In conclusion, the progress achieved in the negotiation process for setting the Sustainable Development Goals presents a solid platform for further progressive work and the opportunity to tackle global challenges.

People's Friendship University of Russia; Moscow State Institute of International Relations, Ministry of Foreign Affairs of the Russian Federation (e-mail: Degterev_Da@pfur.ru, Degterev@mgimo.ru). 
JEL classification: D70, F35, F55.

Keywords: Sustainable Development Goals, United Nations, Global South, donor countries, recipient countries, conflict goals, the Right to Development, Russian Federation.

\section{INTRODUCTION}

The basic questions related to the elaboration of the global development strategy include several eternal issues that preoccupy an expert community: finding the balance between aid recipient's real needs and donor interests (Nelson, 2012); and finding the right theory of development that would really work in the local environment (Burkett and Hart-Landsberg, 2003). Regional specifics should also be taken into consideration, especially when linking economic and political aspects of development, namely the human rights agenda (Ryu and Ortuoste, 2014; Vandernhole and Gready, 2014). National cultural traditions and perceptions are also of great importance in this perspective (Oldfield and Shaw, 2002). How can one get a fully detailed picture of positions of all development process stakeholders and compare regional approaches to development? What kind of methodology is appropriate to use to understand the differences and similarities in stakeholders' positions? Content-analysis of official country statements and their voting in the General Assembly gives us such an opportunity.

\section{INSTITUTIONAL DESIGN OF CONSULTATION PROCESS}

To elaborate the Rio+20 outcome document, "The future we want", the Open Working Group (OWG) of the General Assembly was formed. The main purpose of OWG was to prepare a report containing proposals for Sustainable Development Goals. It seemed reasonable to analyse the way of forming a global approach to a problem of development from a variety of regional approaches, which were later enshrined in the Post-2015 Development Agenda. Special emphasis was paid to the differences in positions among countries, as well as to the position of the Russian Federation as an international donor.

Elaboration of the Sustainable Development Goals and the Post-2015 Development Agenda was characterized by unprecedented inclusive and open consultations with representatives of all interested countries (different groups stakeholders) and covered a wide number of thematic areas. Among the key interested parties (stakeholders) involved in the consultative process, the most active were women (figure 1). In addition, governments opened up the consultative process 
to a number of other interested parties, including volunteer groups and foundations, migrants and their families, the elderly and persons with disabilities, by allowing them to work in close cooperation with the main stakeholders.

\section{Figure 1. Number of statements made by different stakeholders groups}

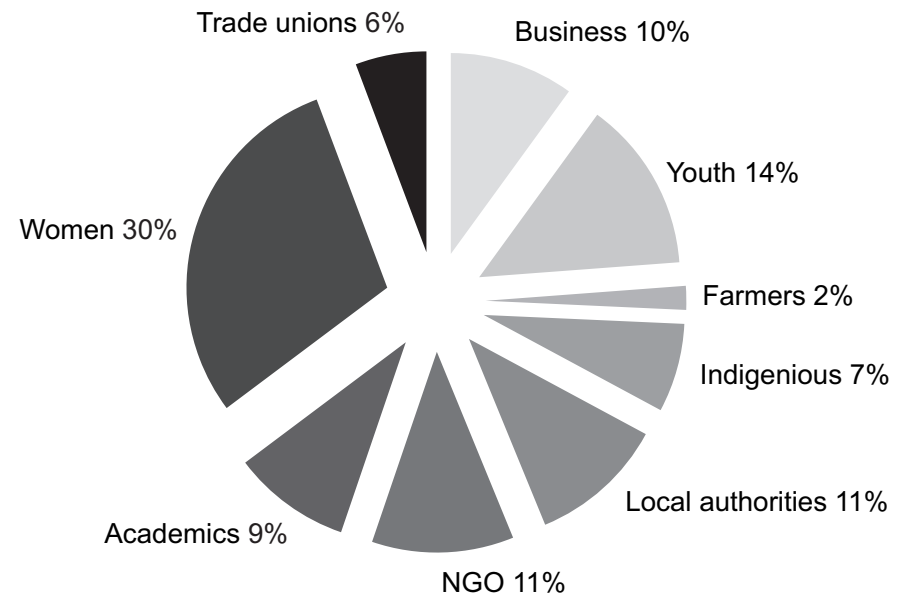

Source: Compiled by the author.

To take into account the positions of the representatives of various countries, the Open Working Group was formed in January 2013. While creating this group, there were some difficulties in reaching an agreement on the distribution of representatives. As a result, the Member States decided to implement an innovative system based on the election of representatives, consisting of 70 Member States and sharing 30 permanent seats. This system was set with respect to the general principles of equitable geographical representation and equal (parity) representation of groups of countries with distinct interests. In the end, seven seats were reserved for African countries, another seven for countries in the Asia-Pacific region, six for Latin American and Caribbean countries and ten for European and North-American countries. High-income countries occupied 10 seats, 12 were allocated to middleincome countries, four were given to countries with various levels of development and four to low-income and least developed countries. Moreover, the latter group was represented mostly by sub-Saharan states in a "one country - one seat mode" (Benin, the Congo and Zambia/Zimbabwe and the United Republic of Tanzania). However, according to some experts, the interest of the poorest countries was underrepresented (Bhattacharya, Khan and Salma, 2014). 
The list of responsibilities of the groups included the representation of its members during each session. ${ }^{1}$ Representatives of other Member States - those that were not allocated a place in the Open Working Group - were allowed to participate and speak on behalf of their respective countries at the Open Working Group meetings. For example, the Russian Federation, which was not included in the Open Working Group, made a number of statements, namely about the undesirability of Sustainable Development Goal 16 and the politicization of the global development agenda (Bartenev, 2015).

Member States were represented in the different regional groups in the Open Working Group (figure 2).

Figure 2. Number of statements made by the different regional groups

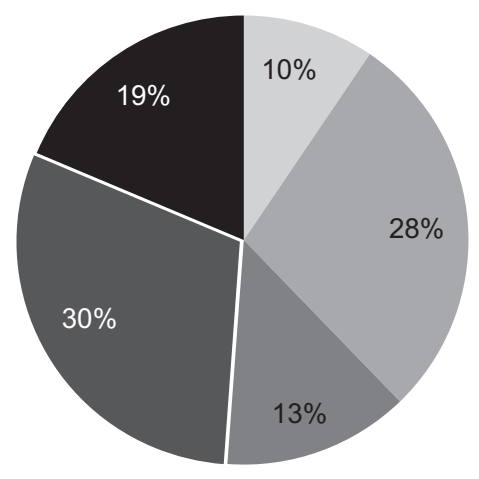

African

Asia-Pacific

Latin America and Caribbean

Western Europe and others

- Eastern Europe

Source: Compiled by the author.

See Progress report of the Open Working Group of the General Assembly on Sustainable Development Goals. Available from https://sustainabledevelopment.un.org/content/documents/ 3238summaryallowg.pdf. 
During the discussions on the Sustainable Development Goals, positions of the countries were presented by separate statements from each country and by joint statements of groups of countries. The following groups made the most statements during the consultation process: Islamic Republic of Iran/Japan/Nepal; Bulgaria/ Croatia; Brazil/Nicaragua; Bangladesh/Republic of Korea/Saudi Arabia; United States/ Canada/Israel, and the groups comprised of countries in Europe (figure 3).

Figure 3. Number of statements made by top 10 groups of countries

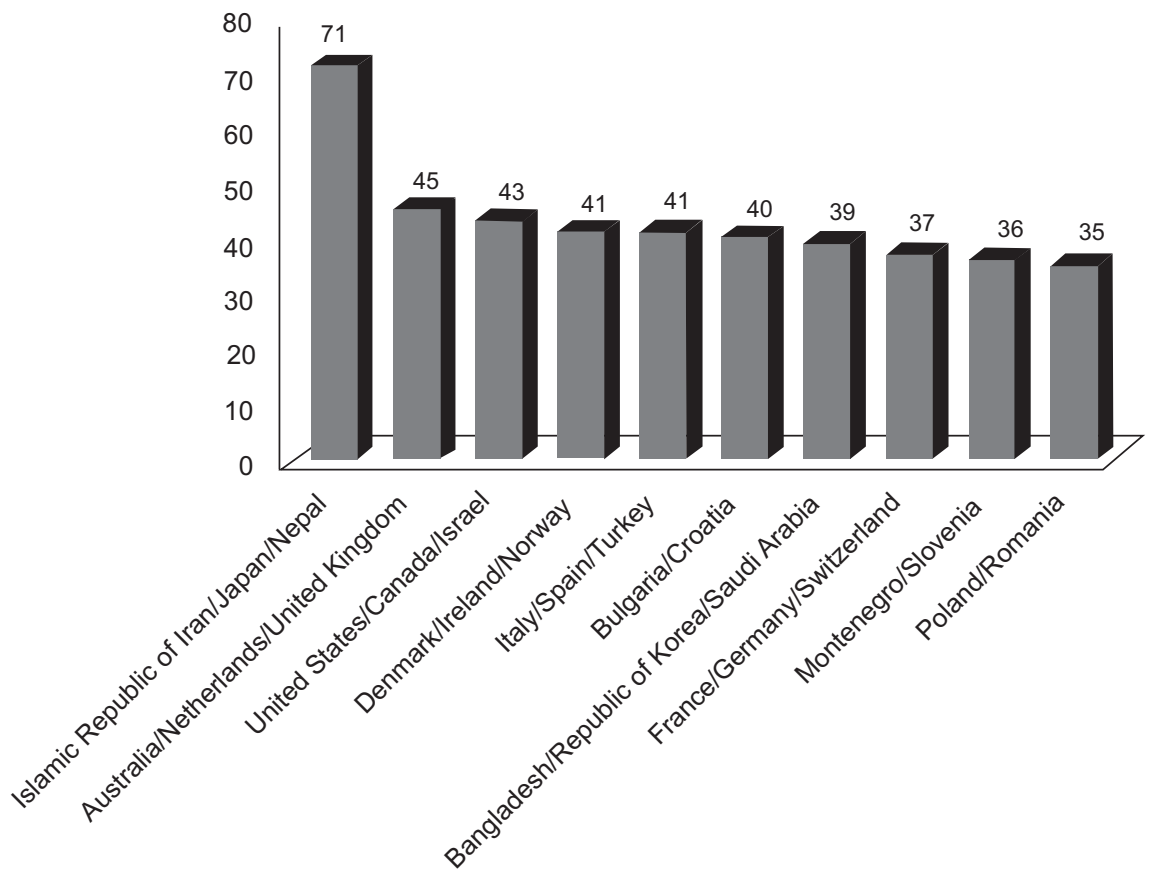

Source: Compiled by the author.

Unfortunately, despite the high level of transparency of the consultation process, at the end of 2015, some of the statements made by the representatives of the Open Working Group that had been posted on the Group's website, https:// sustainabledevelopment.un.org, were removed. In 2016, the rest of the statements, which exceeded 600, were also removed, making it difficult to replicate the content for this research. 


\section{POSITION OF DONOR COUNTRIES}

More than 300 statements made by donor countries during the Opening Working on Sustainable Development Goals sessions were analysed (table 1). Different groups of countries have different interpretations of the concept of poverty, and have a different vision of how to solve this problem (Degterev, 2013b). In this regard, a group of traditional donors - Organisation for Economic Co-operation and Development (OECD) countries, BRICS donors and Arabic donors - Saudi Arabia, the United Arab Emirates, Qatar and Kuwait can be formed.

\section{Table 1. Position of donor countries on Sustainable Development Goals}

\begin{tabular}{|c|c|c|c|}
\hline $\begin{array}{l}\text { Sustainable } \\
\text { Development } \\
\text { Goals }\end{array}$ & Traditional donors & BRICS donors & Arabic donors \\
\hline Goal 1 & $\begin{array}{l}\text { Eradication of poverty } \\
\text { in one generation }\end{array}$ & \multicolumn{2}{|c|}{ Technology, investment and sustainable development } \\
\hline Goal 2 & - & $\begin{array}{l}\text { Access of developing } \\
\text { countries to world } \\
\text { markets; access of all } \\
\text { people to food; } \\
\text { assistance to developing } \\
\text { countries in the } \\
\text { development of } \\
\text { agriculture, technology } \\
\text { and investment }\end{array}$ & $\begin{array}{l}\text { The need to pay attention } \\
\text { to desertification }\end{array}$ \\
\hline Goal 3 & $\begin{array}{l}\text { Investment in youth; } \\
\text { gender equality }\end{array}$ & \multicolumn{2}{|c|}{$\begin{array}{l}\text { Stable migration policy; universal health care; } \\
\text { access to technology; investment in research and } \\
\text { development in developing countries }\end{array}$} \\
\hline Goal 4 & $\begin{array}{l}\text { Equal access to } \\
\text { education }\end{array}$ & \multicolumn{2}{|c|}{ Access to basic education for all } \\
\hline Goal 5 & $\begin{array}{l}\text { Cessation of violence, } \\
\text { access of women to } \\
\text { economic and political } \\
\text { activity }\end{array}$ & $\begin{array}{l}\text { Technical and financial } \\
\text { assistance to developing } \\
\text { countries; equal rights } \\
\text { for women and men }\end{array}$ & $\begin{array}{l}\text { The need to respect the } \\
\text { cultural and religious } \\
\text { traditions of all countries }\end{array}$ \\
\hline Goal 6 & $\begin{array}{l}\text { Universal access to safe } \\
\text { drinking water }\end{array}$ & \multicolumn{2}{|l|}{ Investment and technology } \\
\hline Goal 7 & $\begin{array}{l}\text { Development of } \\
\text { renewable energy and } \\
\text { green energy; efficient } \\
\text { use of energy }\end{array}$ & \multicolumn{2}{|c|}{$\begin{array}{l}\text { Investment in clean energy and the transfer of } \\
\text { technology to developing countries; improving } \\
\text { energy efficiency }\end{array}$} \\
\hline
\end{tabular}


Table 1. (continued)

\begin{tabular}{|c|c|c|c|}
\hline $\begin{array}{c}\text { Sustainable } \\
\text { Development } \\
\text { Goals }\end{array}$ & Traditional donors & BRICS donors & Arabic donors \\
\hline Goal 8 & $\begin{array}{l}\text { Gender equality; decent } \\
\text { work for all }\end{array}$ & $\begin{array}{l}\text { Financial and } \\
\text { technological support, } \\
\text { as well as access to } \\
\text { markets for developing } \\
\text { countries; reform of } \\
\text { global economic } \\
\text { governance to ensure } \\
\text { the participation of } \\
\text { developing countries } \\
\text { in decision-making }\end{array}$ & $\begin{array}{l}\text { Decent work for all; } \\
\text { "green" job }\end{array}$ \\
\hline Goal 9 & $\begin{array}{l}\text { Macroeconomic stability; } \\
\text { policy and regulatory } \\
\text { framework that } \\
\text { encourages private } \\
\text { sector investment; } \\
\text { effective market system }\end{array}$ & $\begin{array}{l}\text { Infrastructure investment } \\
\text { and transfer of } \\
\text { technology to accelerate } \\
\text { the industrialization of } \\
\text { developing countries }\end{array}$ & - \\
\hline Goal 10 & - & $\begin{array}{l}\text { Equality of economic } \\
\text { opportunities for all } \\
\text { countries; strengthening } \\
\text { of international } \\
\text { cooperation, including } \\
\text { the provision of financing } \\
\text { and technology transfer } \\
\text { to developing countries }\end{array}$ & - \\
\hline Goal 11 & $\begin{array}{l}\text { Strengthening of local } \\
\text { and regional authorities; } \\
\text { environment protection; } \\
\text { development of } \\
\text { resource-cities; energy } \\
\text { efficiency and } \\
\text { development of } \\
\text { renewable energy } \\
\text { sources }\end{array}$ & $\begin{array}{l}\text { Provision of funding to } \\
\text { developing countries } \\
\text { to promote sustainable } \\
\text { development of urban } \\
\text { areas }\end{array}$ & $\begin{array}{l}\text { Sustainable transport; } \\
\text { integrated urban planning } \\
\text { and management }\end{array}$ \\
\hline
\end{tabular}


Table 1. (continued)

\begin{tabular}{|c|c|c|c|}
\hline $\begin{array}{l}\text { Sustainable } \\
\text { Development } \\
\text { Goals }\end{array}$ & Traditional donors & BRICS donors & Arabic donors \\
\hline Goal 12 & $\begin{array}{l}\text { Efficient use of } \\
\text { resources and energy; } \\
\text { development of recycling } \\
\text { technologies; private } \\
\text { sector involvement }\end{array}$ & $\begin{array}{l}\text { Changing unsustainable } \\
\text { patterns of production } \\
\text { and consumption in } \\
\text { developed countries; } \\
\text { improving access of } \\
\text { developing countries to } \\
\text { markets of products } \\
\text { and technologies; } \\
\text { reducing energy } \\
\text { consumption and waste } \\
\text { in developed countries }\end{array}$ & - \\
\hline Goal 13 & $\begin{array}{l}\text { Environmental protection; } \\
\text { sustainable patterns of } \\
\text { production and } \\
\text { consumption; sustainable } \\
\text { urban development }\end{array}$ & $\begin{array}{l}\text { Emissions reductions in } \\
\text { developed countries; } \\
\text { providing financial and } \\
\text { technical support to } \\
\text { developing countries }\end{array}$ & $\begin{array}{l}\text { Urgent action to mitigate } \\
\text { and adapt to climate } \\
\text { change }\end{array}$ \\
\hline Goal 14 & $\begin{array}{l}\text { Expansion of existing } \\
\text { contracts; elimination } \\
\text { of illegal and unregulated } \\
\text { fishing }\end{array}$ & - & - \\
\hline Goal 15 & $\begin{array}{l}\text { Good governance of } \\
\text { natural resources }\end{array}$ & - & $\begin{array}{l}\text { Protection and restoration } \\
\text { of terrestrial ecosystems; } \\
\text { inadmissibility of } \\
\text { biodiversity loss }\end{array}$ \\
\hline Goal 16 & $\begin{array}{l}\text { Private investments } \\
\text { political and economic } \\
\text { reforms to create an } \\
\text { attractive investment } \\
\text { climate }\end{array}$ & $\begin{array}{l}\text { Strengthening of } \\
\text { South-South cooperation; } \\
\text { assistance to developing } \\
\text { countries }\end{array}$ & $\begin{array}{l}\text { Strengthening of the } \\
\text { global partnership for } \\
\text { sustainable } \\
\text { development; } \\
\text { transfer of technology to } \\
\text { developing countries }\end{array}$ \\
\hline Goal 17 & $\begin{array}{l}\text { Improving the global } \\
\text { trading and financial } \\
\text { system }\end{array}$ & $\begin{array}{l}\text { Improving the global } \\
\text { financial system; } \\
\text { investment and } \\
\text { technology }\end{array}$ & - \\
\hline
\end{tabular}

Source: Compiled by the author. 
Based on the analysis of countries statements, the positions of donors can be divided into two groups: positions held by the developed Western countries group or the traditional donors (members of the OECD Development Assistance Committee), and those held by new donors (BRICS) and Arab donors. BRICS and Arab donors have taken the side of developing countries. This is apparent from the content of their speeches and frequent references and statements of solidarity of developing countries, in particular with the Group of 77 and China, the Caribbean Community (CARICOM) and the African Group. In pursuit of the same objectives in the face of poverty eradication, the elimination of all kinds of inequalities, achieving the sustainable development, ensuring security at the global level, these countries hold different views in their approaches.

In particular, Saudi Arabia has declared the need for equal access to energy, as this will have a positive impact on many other development issues, such as education, health, water and agriculture. In the framework of these activities, the provision of technology, "green energy" to developing countries will be very important. ${ }^{2}$ Actively supporting this position, countries have mentioned the problem of the inequality of access to technology, which can be attributed to the reluctance of developed countries to share the innovations and have pointed out the negative consequences associated with this, particularly with regard to the containment of development process. Along with the technology, emphasis has been placed on the issue of investment of developed countries in developing countries, and the need of investments for the development is stressed. It is stated that the international community should create favourable economic conditions and a favourable environment for trade and investment in order to accelerate the reform of global economic governance by increasing the representation and participation of developing countries and establishing a fair international economic and financial system so that the people of all countries can benefit equally from global economic development. ${ }^{3}$

In addition, these countries believe that the goals and objectives should be indicative and not mandatory or prescriptive. Member states should be free to pursue those aims and objectives, which, in their opinion, fit their own policy, the environment and their national priorities and characteristics, as this will ensure the successful achievement of the goals and objectives. ${ }^{4}$

2 Statement by Saudi Arabia, Debate on economic growth, industrialization, infrastructure and energy, 2 April 2014.

3 Statement by India, Debate on poverty eradication, 18-19 April 2013.

4 Statement by India, Means of implementation and global partnership for sustainable development, 9 May 2014. 
Issues, such as social, political rights, gender equality, access to clean water and sanitation, provision of adequate health care, equal access to education, the rational use of natural resources, respect for the environment, water spaces, adaptation to environmental changes, achieving global governance, conflict prevention, post-conflict world order and the promotion of durable peace, the rule of law, the involvement of the private sector for the tasks are more touched upon by developed countries than developing ones.

Traditional donors also consider the eradication of poverty as one of the main tasks, but they propose other solutions. In the long term, poverty reduction and shared prosperity require rapid economic recovery. This rise is also required to ensure peace and global security in order to create jobs. Economic growth and trade are the main factors of national and international prosperity. However, this vision brings forward a divergence of views between developed and developing countries. For instance, developing countries insist on providing technology and investment, while develop countries persist in the opinion that developing countries should create favourable conditions for attracting investments, and that developed countries can only support them in this endeavour and assist them in the effective use of finances. The improvement and strengthening of internal resources, in particular, the improvement of the tax system and the elimination of corruption are considered to be basic measures to improve the investment climate. Developed countries do not believe that they should be the only source of investment and financial resources for developing ones; they also advocate the involvement of the private sector and different organizations. ${ }^{5}$

The issue of overcoming poverty is seen in close connection with the issue of environmental degradation at global, regional and local levels, which exacerbate social and economic problems. According to the developed countries, it is necessary to recognize the links between environmental, social and economic goals and to realize that a healthy environment favours economic and social development. ${ }^{6}$ Sustainable management of natural resources is essential for the eradication of poverty and the creation of lasting, sustainable growth and protecting the environment for future generations. BRICS and Arab donors, as well as traditional donors also raised the issue of energy, but in contrast to other donors, they consider the development of green energy, investments in renewable and efficient energy use as the main ways for solving problems in this area. Developing countries see the solution

Statement by United Kingdom, Debate on global partnership for achieving sustainable development, 10 December 2013.

6 Statement by France, Proposal for statement on economic growth, employment and infrastructure, 12 May 2014. 
to the problem of environmental pollution in developed countries as being in accordance with their historical responsibility, making it necessary for them to take the lead in reducing emissions and providing adequate financial and technical support to developing countries.

Considering the issue of global governance, developed countries believe that it should work to support integration. ${ }^{7}$ This will require enhanced cooperation between the relevant actors and better integration of all aspects of sustainable development, which, in turn, will lead to greater consistency in the decision-making process and increase the effectiveness of the development on the basis of agreed principles. In fact, global governance is equal to the global partnership in that active participation of civil society and not only States is required. The joint solution of current challenges is vital in order to overcome conflicts, violence and instability, which are the most crucial obstacles to global development. At the global level, these obstacles undermine development. No country alone can solve these problems; collective action is indeed needed to address these issues. Violence can be prevented. It is not inevitable. Investment in conflict prevention may accelerate overall economic development.

\section{POSITION OF AID RECIPIENT COUNTRIES}

In addition to statements of donor countries, the statements of the recipient countries of Africa, South-East Asia, Latin America, the Caribbean and small island developing States were analysed. Similar to donor countries, recipient countries hold differing positions on the Sustainable Development Goals among each other (table 2).

The positions of the recipient countries are as diverse as the positions of the donor countries. However, the recipient countries' positions on some issues were quite similar, including, with regard to eradication of poverty, protection of the rights of migrant workers and the sustainable use of the oceans, seas and marine resources. On the issue of poverty eradication, all groups of countries expressed the need to focus not only on people in extreme poverty, but also on people living just above the poverty line and those who are at risk of falling into poverty. In addition, the eradication of poverty requires strong and inclusive economic growth and the elimination of corruption.

7 Statement by Germany, Post-2015 Agenda for Sustainable Development: key positions of the German Government, 15 February 2015. 


\section{Table 2. Position of aid recipient countries on the Sustainable Development Goals}

\begin{tabular}{|c|c|c|}
\hline $\begin{array}{l}\text { Sustainable } \\
\text { Development } \\
\text { Goals }\end{array}$ & African countries & Asian and Latin American countries \\
\hline Goal 1 & \multicolumn{2}{|c|}{$\begin{array}{l}\text { Eradication of extreme poverty; attention to people living not only in extreme } \\
\text { poverty, but to those living just above the poverty line; sustainable and inclusive } \\
\text { economic growth; the elimination of corruption; the elimination of discrimination } \\
\text { and inequality }\end{array}$} \\
\hline Goal 2 & $\begin{array}{l}\text { Increasing agricultural production in } \\
\text { developing countries; the fight against } \\
\text { drought; reduction of subsidies in the } \\
\text { agricultural sector in developed } \\
\text { countries; sustainable ecosystem } \\
\text { approach to land management; } \\
\text { transfer of technology to African } \\
\text { countries for the development } \\
\text { of agriculture }\end{array}$ & $\begin{array}{l}\text { Reduction of agricultural subsidies in } \\
\text { developed countries; transfer of } \\
\text { technology to developing countries for } \\
\text { agricultural development }\end{array}$ \\
\hline Goal 3 & \multicolumn{2}{|c|}{$\begin{array}{l}\text { Increase in life expectancy to at least } 60 \text { years; universal access to health } \\
\text { services and essential drugs and vaccines; zero maternal and infant mortality; } \\
\text { universal access to HIVIAIDS treatment; strengthening of national health } \\
\text { systems; elimination of environmental causes of diseases }\end{array}$} \\
\hline Goal 4 & \multicolumn{2}{|c|}{$\begin{array}{l}\text { Universal, free and qualitative primary and secondary education for all children; } \\
\text { achieving } 100 \% \text { literacy rate among adults and young people; elimination of } \\
\text { gender discrimination in educational institutions }\end{array}$} \\
\hline \multirow[t]{2}{*}{ Goal 5} & \multicolumn{2}{|c|}{$\begin{array}{l}\text { By } 2030 \text { the cessation of all forms of discrimination against women; no violence; } \\
\text { equal participation of women in decision-making in public and private institutions; } \\
\text { equal employment opportunities for women and equal pay for equal work }\end{array}$} \\
\hline & Prohibition of child and early marriage & - \\
\hline Goal 6 & \multicolumn{2}{|c|}{$\begin{array}{l}\text { Improving the efficiency of water use in agriculture; access to safe drinking water } \\
\text { in homes, schools and health facilities }\end{array}$} \\
\hline Goal 7 & \multicolumn{2}{|c|}{$\begin{array}{l}\text { A decrease in energy prices and achieving } 100 \% \text { access to electricity for the } \\
\text { population of developing countries by } 2030 \text {; increase energy efficiency; promote } \\
\text { the use of environmentally sound energy technologies in developing countries; } \\
\text { technology transfer, financing and investment in the energy sector in developing } \\
\text { countries }\end{array}$} \\
\hline
\end{tabular}


Table 2. (continued)

\begin{tabular}{|c|c|c|}
\hline $\begin{array}{l}\text { Sustainable } \\
\text { Development } \\
\text { Goals }\end{array}$ & African countries & Asian and Latin American countries \\
\hline \multirow[t]{2}{*}{ Goal 8} & $\begin{array}{l}\text { Achievement of } 6-7 \% \text { economic } \\
\text { growth in low-income countries; } \\
\text { creation of new jobs in developing } \\
\text { countries }\end{array}$ & $\begin{array}{l}\text { Creation of decent jobs with decent } \\
\text { wages, without discrimination; support } \\
\text { family businesses to create jobs; } \\
\text { support of countries with low and } \\
\text { middle-income }\end{array}$ \\
\hline & \multicolumn{2}{|c|}{$\begin{array}{l}\text { Protection of the rights of all workers, including migrant workers, in accordance } \\
\text { with the fundamental rights of the International Labour Organization }\end{array}$} \\
\hline Goal 9 & \multicolumn{2}{|c|}{$\begin{array}{l}\text { Implementation of the Bali Strategic Plan for Technology Support and Capacity } \\
\text { Building; }{ }^{\text {a }} \text { ensure the full functioning of a capacity-building and technology } \\
\text { support database to promote the development of technological capacity of } \\
\text { developing countries }\end{array}$} \\
\hline \multirow[t]{2}{*}{ Goal 10} & $\begin{array}{l}\text { Cessation of all forms of foreign } \\
\text { occupation and colonial domination }\end{array}$ & $\begin{array}{l}\text { Protection of rights and fundamental } \\
\text { freedoms without discrimination on } \\
\text { any ground }\end{array}$ \\
\hline & \multicolumn{2}{|c|}{$\begin{array}{l}\text { Ensuring equality of access to technology and innovation; decrease in income } \\
\text { inequality among countries; increased investment in the social and economic } \\
\text { infrastructure and human resources development in developing countries }\end{array}$} \\
\hline Goal 11 & $\begin{array}{l}\text { To make all cities accessible to } \\
\text { people with disabilities by } 2030 \text {; } \\
\text { to ensure access of all people to } \\
\text { decent and affordable housing }\end{array}$ & $\begin{array}{l}\text { Investment in developing countries to } \\
\text { build "clean" cities; elimination of } \\
\text { slums; sustainable and integrated } \\
\text { rural and urban development }\end{array}$ \\
\hline Goal 12 & - & $\begin{array}{l}\text { Technology and investment to } \\
\text { developing countries }\end{array}$ \\
\hline Goal 13 & - & $\begin{array}{l}\text { Technology transfer and investment in } \\
\text { developing countries to mitigate and } \\
\text { adapt to climate change }\end{array}$ \\
\hline Goal 14 & \multicolumn{2}{|c|}{$\begin{array}{l}\text { Prevention of marine pollution and limiting emissions and waste disposal into the } \\
\text { sea; restoration and protection of marine ecosystems from destruction }\end{array}$} \\
\hline Goal 15 & \multicolumn{2}{|l|}{ Cessation of logging and reforestation } \\
\hline Goal 16 & \multicolumn{2}{|c|}{$\begin{array}{l}\text { Democratization of international institutions; access of developing countries to } \\
\text { international decision-making; strengthening regulation of financial markets and } \\
\text { institutions to ensure global financial stability; reform of the international monetary } \\
\text { system }\end{array}$} \\
\hline
\end{tabular}


Table 2. (continued)

\begin{tabular}{l|l|l}
\hline $\begin{array}{c}\text { Sustainable } \\
\text { Development } \\
\text { Goals }\end{array}$ & \multicolumn{1}{|c}{ African countries } & Asian and Latin American countries \\
\hline Goal17 & $\begin{array}{l}\text { Elimination of all trade protectionist measures to increase the exports of } \\
\text { developing countries; return of all illegal financial resources to their countries of } \\
\text { origin; development of an open, predictable, nondiscriminatory trading and } \\
\text { financial system; reform of major international economic organizations such } \\
\text { as the World Bank, the International Monetary Fund (IMF) for a balanced and } \\
\text { democratic regional representation by } 2020\end{array}$ \\
\hline
\end{tabular}

Source: Compiled by the author.

Note: $\quad{ }^{a}$ For details about the Bali Strategic Plan, see www.unep.org/ozonaction/About/BaliStrategicPlan/tabid/ 1060467/Default.aspx.

Countries also are in total agreement on the sustainable use of the oceans, seas and marine resources. Most developing countries are coastal States and their well-being depends largely on the state of the marine environment. As a result, this group of countries advocates for pollution prevention and the limitation of emissions and waste in the sea. In addition, developing countries call for respect of international law and the joint elimination of illegal and unregulated fishing. The greatest concern on issues related to water resources has been shown by developing States representing small islands. These countries have repeatedly raised questions about the rise of the sea level, and the restoration and protection of marine ecosystems from destruction. ${ }^{8}$ The positions of the countries on protection, restoration and sustainable use of terrestrial ecosystems are also very close. Countries have expressed concern about deforestation and called for reforestation. In addition, all countries agree that it is necessary to ensure sustainable management of forests and mountain ecosystems and to stop the loss of biodiversity.

As for the gender equality, countries indicate quite similar positions. Recipient countries support: ending all forms of discrimination against women by 2030; the cessation of violence; women's equal participation in decision-making in public and private institutions; enhancing the role of women in the economy; equal employment opportunities for women and men; and equal pay for equal work. The only controversial is on the issue of early marriages. African countries express the need for the prohibition of early marriage, while most of the developing countries take the view that national and cultural traditions should be respected.

8 Statement by Pacific small island developing States, Debate on climate change and disaster risk reduction, 9 January 2014. 
The general idea, passed almost through all the statements of the Group of 77 , was expressed by the representative of Bangladesh during the first meeting of Open Working Group, who stated the following: developing countries still did not have enough money to achieve the Sustainable Development Goals, thus an integral part of the solution of all the issues should be investment, financial assistance and transfer of technology to developing countries. ${ }^{9}$

\section{CONFLICT OF INTERESTS IN ELABORATION OF UNIVERSAL GOALS}

The process of elaborating a universal approach to development issues shared by countries with different levels of socioeconomic development and civilization features is not new to the United Nations. It is worth recalling the adoption of the International Covenants on Human Rights in 1966 after almost 20 years of discussion. Western countries pushed mainly for political rights, focusing on the French Declaration of the Rights of Man and of the Citizen of 1789 and the United States Constitution of 1787 and proclaiming the natural character of human rights and fundamental freedoms in line with the concepts of $\mathrm{J}$. Locke and T. Hobbes, but initially opposed the inclusion of socioeconomic rights in the International Covenant on Civil and Political Rights. In turn, the former Union of Soviet Socialist Republics and the other socialist countries insisted on the inclusion of these documents in a wide range of socioeconomic rights, objecting to certain civil and political rights. Developing countries occupied a special position, mainly because of the attitude of Islamic States to the rights of women (Sarkar, 2009, pp. 200-206).

Following the discussions, General Assembly resolution 2200(XXI) was adopted, which contains a general preamble and a concluding article along with three separate international instruments: International Covenant on Economic, Social and Cultural Rights; International Covenant on Civil and Political Rights; and Optional Protocol to the International Covenant on Civil and Political Rights. Voting for each of the three documents was held separately. The total number of Member States at that time was 122; 104 States voted for the adoption of the International Covenant on Economic, Social and Cultural Rights while 18 did not vote. For the adoption of the International Covenant on Civil and Political Rights, 102 states voted in favour of it while 3 abstained and 17 did not vote. Finally, the adoption of the Optional Protocol establishing the Human Rights Committee was voted on by 76 countries, 18 countries (including the socialist countries) voted "against", while 13 countries abstained and 15 did not vote.

9 Statement by Bangladesh, Statement under agenda item 3: general discussions, 14-15 March 2013. 
Another historical example within the United Nations was the adoption of the Declaration on the Right to Development. The United Nations Human Rights Commission established in 1981 the Working Group of Governmental Experts on the Right to Development, consisting of 15 experts. The Declaration on the Right to Development elaborated by the Working Group was adopted in 1986 by the General Assembly in resolution $41 / 128$ by a majority of 146 votes in favour, one vote "against" (the United States of America), eight abstentions (the United Kingdom of Great Britain and Northern Ireland, Denmark, Iceland, Israel, Finland, Germany, Sweden and Japan) and four not voting. The Declaration certainly reflected the interests of developing countries - aid recipients, and to a lesser extent was in the interests of the donor countries. Subsequently, the resolution "Right to development" is adopted each year by the General Assembly.

In contrast to the Millennium Development Goals, which were aimed at increasing the socioeconomic level of the recipient countries, the Sustainable Development Goals relate to quality of life of both donor and recipient countries; they can be characterized as being universal goals. Accordingly, the emphasis was significantly shifted from the problems of the developing countries to developed ones. Instead of the three Millennium Development Goals related to health care (Millennium Development Goals 4-6) and one environmental goal (Millennium Development Goal 7), there are three goals related to the environment (Sustainable Development Goals 13-15) and only one goal pertaining to the health sector (Sustainable Development Goal 3). In addition to socioeconomic goals, there is also a political one (Sustainable Development Goal 16). Finally, in the Millennium Development Goals only the goals were identified, but not the means to achieve it, with the exception of Goal 8, while each Sustainable Development Goal has a number of subitems for its practical implementation (special paragraphs $a, b, c, \ldots$ for each goal). On the one hand, the presence of such subparagraphs specifies the commitments, but, on the other hand, there are several paths of development that may eventually lead to the desired socioeconomic indicators. Excessive detail should not lead us to the "only right" path of development to achieve each of the goals.

There is no denying that an attempt to combine the goals for developed and developing countries in a number of cases may lead to a conflicting target. Here are some of the most obvious examples: Goal 7, target 7.1 requires access to cheap energy, while Goal 12, target c stipulates the need to rationalize subsidies to fossil-fuel subsidies. In poor countries that provide natural resources, fuel subsidies allow ordinary citizens to get access to cheap energy. Another example, in Goal 2, target 1 , and Goal 2, target 3, the need to use more fish in the diet is implied, while Goal 14, targets 4 and 6 refer to preventing overfishing. Finally, Goal 9, targets 1 and 2 make reference to revitalization of infrastructure development and the speedy 
industrialization, while in Goal 9, target 4, the priorities of development of green technologies are stipulated. As the example of China shows, the country initially strived for large-scale industrialization, reaching a leading position in a number of markets on a global scale, and then began to pay more attention to the quality of economic growth. Would China have achieved the same success, if the drive for industrialization had been originally conceived primarily for green technologies, rather than for scale of production? Hardly. Industrialization is important for a number of developing countries, while developed countries have already developed an industrial base and are now seeking cleaner production. Though of course, in many cases, this refers to the fragile ecosystems in developing countries (for example, in small island States).

Often criticism is directed at the goals that can stand for certain business interests. In contrast to the Millennium Development Goals, the pharmaceutical industry is considered to be left out in the cold in the formulation of the Sustainable Development Goals (for reasons already mentioned), while in the first position this time comes tourist lobby with the introduction of the concept of "sustainable tourism" (Sustainable Development Goal 8, target 9 and Sustainable Development Goal 12, target b) without any reference to the poorest countries. For example, tourism in traditional European routes also falls under this concept.

One way to reconcile developed and developing countries in assuming their responsibility for sustainable development could be through an approach based on the principle of Common But Differentiated Responsibility (CBDR), which has been constantly mentioned by $\mathrm{G} 77+$ China representatives in its statements and has been set out in the Rio+20 outcome document, "The future we want". In the document, CBDR is proposed to serve as a key approach, which implies that the Sustainable Development Goals should not place additional burdens on developing countries, but, instead, donor countries should be required to respect their international commitments concerning financial resources, capacity and technology transfer.

\section{RUSSIAN FEDERATION AS A DONOR}

National priorities in the area of the development assistance were set out initially in the Concept of Russia's Participation in International Development Assistance, signed by the country's president, Vladimir Putin, on the 14 June $2007 .^{10}$ Even though it refers to the consistent implementation of the Concept ".... in accordance with the Action Plan on Russian participation in the IDA [international

10 Concept of the Russian's Participation in International Development Assistance, 25 June 2007. Available from http://archive.mid.ru/brp_4.nst/0/571FEF3D5281FE45C32573050023894F. 
development assistance], approved by the Russian Government on the three-year period", further strengthening the capacity of the Russian Federation as an international donor slowed and a corresponding action plan was not adopted (Degterev, 2013a). In 2014 the Concept of the Russian Federation's state policy in the Sphere of International Development Assistance was adopted, ${ }^{11}$ advancing the guidelines of the first concept. Formation of a national mechanism for providing IDA continues. The positions of the Russian Federation towards the Millennium Development Goals can be traced by two indicators: the annual vote of the Russian Federation in the General Assembly for the resolution on the right to development (table 3) and through remarks made by Sergey Lavrov, the Foreign Minister of the Russian Federation, at the United Nations Summit for the Adoption of the Post-2015 Development Agenda, in New York on 27 September 2015.

The results of the vote on the General Assembly resolution on the right to development can be considered as an important indicator of the attitude of different groups of countries towards issues related to sustainable development. This resolution is adopted annually. It was first adopted in 1986 after the adoption of the landmark declaration on the Right to Development. During the period 1987-1996 and in the 2000 resolution of the right to development, it was adopted without a vote. The Russian Federation (up to 1991 the Union of Soviet Socialist Republics (USSR)) has always supported this resolution, together with the countries comprising the Global South such as Argentina, Brazil, Mexico, China, and Saudi Arabia. The United States has traditionally voted against the resolution. Positions of the other leading world countries, members of the $\mathrm{G} 20$ vary between these two poles.

Even though the international development assistance issue is not present in the broad public discourse of the Russian Federation in the relevant documents and reports, and is a rather narrow path of research for some experts, the country's minister of foreign affairs, broadly touched on this topic in a public speech at the anniversary summit of the United Nations. During the address, he actually marked the attitude of the Russian Federation to the basic goals of sustainable development. ${ }^{12}$ In this regard, it is worth conducting a detailed analysis of the country's attitude towards the Sustainable Development Goals.

\footnotetext{
11 Concept of State Policy of the Russian Federation in the Field of International Development Assistance. Approved by Presidential Decree of 20 April 2014 No. 259. Available from http:// archive.mid.ru/ns-osndoc.nsf/0e9272befa34209743256c630042d1aa/00cc9154529e1c7fc32575 bc002c6bb5.

12 Remarks by the Ministry for Foreign Affairs, Russian Federation, made by Sergey Lavrov at the United Nations Summit for the Adoption of the Post-2015 Development Agenda, New York, 27 September 2015. Available from www.mid.ru/foreign_policy/news/-/asset_publisher/cKNonkJE02Bw/ content/id/1794073?p_p_id=101_INSTANCE_cKNonkJEO2Bw\&_101_INSTANCE_cKNonkJE02Bw_ languageld=en_GB.
} 


\begin{tabular}{|c|c|c|c|c|c|c|c|c|c|c|c|c|c|}
\hline \multirow{19}{*}{ 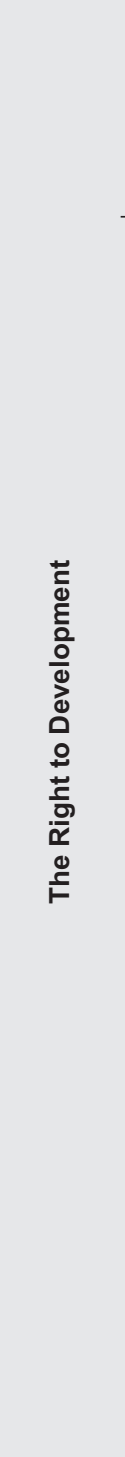 } & GSL/OL/S $\exists Y / \forall$ & GレOZてレ゙L & $>$ & $\varangle$ & $>$ & $z$ & $>$ & $\varangle$ & $\varangle$ & $>$ & $>$ & $>$ & $z$ \\
\hline & L $8 \mathrm{~L} / 69 / \mathrm{S} \exists \mathrm{d} / \forall$ & カレーでてレ゙レ & $>$ & $\varangle$ & $>$ & z & $>$ & $>$ & $\varangle$ & $>$ & $>$ & $>$ & $\varangle$ \\
\hline & 8SL/89/S $\exists$ d/ $\forall$ & ๕レOZ゙てレ゙レ & $>$ & $\varangle$ & $\succ$ & $z$ & $>$ & $>$ & $\varangle$ & $>$ & $>$ & $\succ$ & $\varangle$ \\
\hline & LLL/L9/S $\exists Y / \forall$ & てレOZてレナOZ & $>$ & $\varangle$ & $>$ & $z$ & $>$ & $>$ & $\varangle$ & $>$ & $>$ & $>$ & $\varangle$ \\
\hline & GSL/99/S $\exists$ Y $/ \forall$ & ルーでてレ6レ & $>$ & $\varangle$ & $>$ & z & $>$ & $>$ & $\varangle$ & $>$ & $>$ & $\ll$ & $\ll$ \\
\hline & 6IZ/S9/S $\exists y / \forall$ & 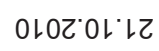 & $>$ & $z$ & $>$ & $z$ & $>$ & $\varangle$ & $z$ & $>$ & $>$ & $\ll$ & $z$ \\
\hline & 乙LL/†9/S $\exists Y / \forall$ & 600Zてレ゙ーレ & $>$ & $z$ & $>$ & $z$ & $>$ & $\varangle$ & $z$ & $>$ & $>$ & $\ll$ & $\varangle$ \\
\hline & 8LL/E9/S $\exists \mathrm{U} / \forall$ & 800Z゙てレ゙レ & $>$ & $>$ & $>$ & $\varangle$ & $>$ & $>$ & $>$ & $>$ & $>$ & $>$ & $>$ \\
\hline & I9L/Z9/S $\exists Y / \forall$ & ட00Zててレ'8レ & $>$ & $z$ & $>$ & $z$ & $>$ & $z$ & $z$ & $>$ & $>$ & $z$ & $z$ \\
\hline & $69 \mathrm{l} / \mathrm{L} 9 / \mathrm{S} \exists \mathrm{d} / \mathrm{H}$ & 900Z゙てレ6レ & $>$ & $z$ & $>$ & $z$ & $>$ & $z$ & $z$ & $>$ & $>$ & $z$ & $z$ \\
\hline & LSL/09/S $\exists Y / \forall$ & ૬00Z゙て・9レ & $>$ & $\varangle$ & $>$ & $\varangle$ & $>$ & $>$ & $>$ & $>$ & $>$ & $>$ & $\ll$ \\
\hline & G৪L/6S/S $\exists \mathrm{U} / \forall$ & †00Z゙レ・0Z & $>$ & $\varangle$ & $>$ & $\varangle$ & $>$ & $>$ & $>$ & $>$ & $>$ & $>$ & $\varangle$ \\
\hline & ZLL/8S/S $\exists Y / \forall$ & ย00ででてて & $>$ & $\varangle$ & $>$ & $\varangle$ & $>$ & $>$ & $>$ & $>$ & $>$ & $>$ & $\varangle$ \\
\hline & $\varepsilon Z Z / L S / S \exists y / \forall$ & て00でてレ৪ & $>$ & $z$ & $>$ & $\varangle$ & $>$ & $\varangle$ & $\varangle$ & $>$ & $>$ & $\varangle$ & $\ll$ \\
\hline & OSL/9S/S $\exists Y / \forall$ & レ00Zてレ゙ட & $>$ & $\varangle$ & $>$ & $\varangle$ & $>$ & $\varangle$ & $\varangle$ & $>$ & $>$ & $\varangle$ & $z$ \\
\hline & $G \angle L / t G / S \exists Y / \forall$ & 666เてレ゙レ & $>$ & $\varangle$ & $>$ & $z$ & $>$ & $\varangle$ & $z$ & $>$ & $>$ & $\varangle$ & $z$ \\
\hline & 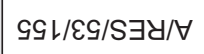 & 866レてで60 & $>$ & $\varangle$ & $>$ & $\varangle$ & $>$ & $\varangle$ & $\varangle$ & $>$ & $>$ & $\varangle$ & $\varangle$ \\
\hline & 9عL/ZS/S $\exists y / \forall$ & ட66เてレ゙レ & $>$ & $>$ & $>$ & $z$ & $>$ & $\varangle$ & $\varangle$ & $>$ & $>$ & $\varangle$ & $z$ \\
\hline & $\varepsilon \varepsilon\llcorner/ L / S \exists y / \forall$ & 986レ゙てレ゙っ0 & $>$ & $\varangle$ & $>$ & $z$ & $>$ & $z$ & $z$ & $>$ & $>$ & $z$ & $z$ \\
\hline 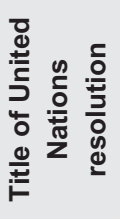 & 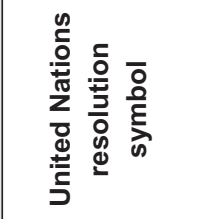 & 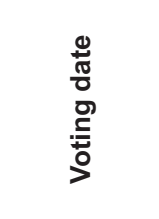 & 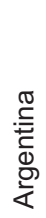 & 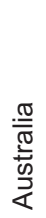 & $\begin{array}{l}\overline{\bar{N}} \\
\overline{\mathscr{N}} \\
\bar{\emptyset}\end{array}$ & $\begin{array}{l}\frac{\mathbb{T}}{0} \\
\frac{\mathbb{D}}{\mathbb{T}} \\
\text { U }\end{array}$ & $\frac{\mathbb{\sigma}}{\frac{5}{\frac{1}{U}}}$ & 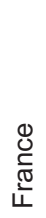 & 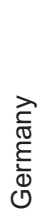 & $\begin{array}{l}\underline{\underline{0}} \\
\underline{\underline{C}}\end{array}$ & $\begin{array}{l}\frac{\pi}{0} \\
\Phi \\
\stackrel{0}{0} \\
\frac{0}{0} \\
\end{array}$ & 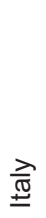 & 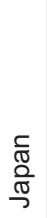 \\
\hline
\end{tabular}




\begin{tabular}{|c|c|c|c|c|c|c|c|c|c|c|}
\hline \multirow{19}{*}{ 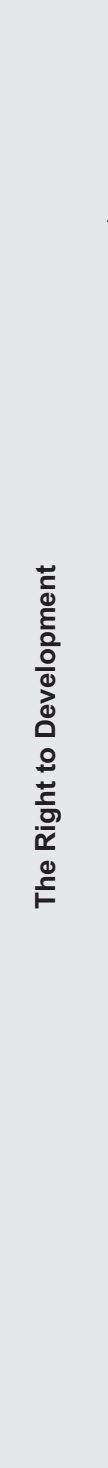 } & SGL/0L/S $\exists Y / \forall$ & SレOZてレ゙L & $>$ & $\varangle$ & $\varangle$ & $\varangle$ & $\varangle$ & $\varangle$ & z & $z$ \\
\hline & เ৪L/69/S $\exists y / \forall$ & †レ০ててレ・8ト & $>$ & $\varangle$ & $>$ & $>$ & $>$ & $>$ & $z$ & $z$ \\
\hline & 8GL/89/S $\exists Y / \forall$ & ๕レOZ゙てレ৪レ & $>$ & $\varangle$ & $\succ$ & $>$ & $>$ & $>$ & $\mathbf{z}$ & $z$ \\
\hline & LLL/L9/S $\exists y / \forall$ & てレ০Zてレ・OZ & $>$ & $\varangle$ & $>$ & $>$ & $>$ & $>$ & $z$ & $z$ \\
\hline & sGL/99/S $\exists$ d/ $\forall$ & ルレててで6レ & $>$ & $\varangle$ & $>$ & $>$ & $>$ & $>$ & $\mathbf{z}$ & $z$ \\
\hline & 6IZ/G9/S $\exists y / \forall$ & OLOZOレレZ & $>$ & $z$ & $>$ & $>$ & $>$ & $\varangle$ & $z$ & $z$ \\
\hline & 乙Lレ/†9/S $\exists Y / \forall$ & 600Zててレ・8レ & $>$ & $\varangle$ & $>$ & $>$ & $>$ & $\varangle$ & $\mathbf{z}$ & $z$ \\
\hline & 8LL/ع9/S $\exists \mathrm{d} / \forall$ & 800Zててレ・8レ & $>$ & $>$ & $>$ & $>$ & $>$ & $>$ & $>$ & $z$ \\
\hline & I9L/Z9/S $\exists y / \forall$ & LOOZててレ'৪レ & $>$ & z & $>$ & $>$ & $>$ & $z$ & $z$ & $z$ \\
\hline & $69 \mathrm{~L} / \mathrm{L} 9 / \mathrm{S} \exists \mathrm{d} / \forall$ & 900Zでレ6レ & $>$ & $z$ & $>$ & $>$ & $>$ & $z$ & $z$ & $z$ \\
\hline & LGL/09/S $\exists Y / \forall$ & ভ00Z゙てレ・9レ & $>$ & $>$ & $>$ & $>$ & $>$ & $>$ & $>$ & $z$ \\
\hline & s৪L/6G/S $\exists y / \forall$ & †00Z゙レ・0乙 & $>$ & $>$ & $>$ & $>$ & $>$ & $>$ & $>$ & $z$ \\
\hline & 乙LL/8S/S $\exists \mathrm{d} / \forall$ & ย૦૦でてレてて & $>$ & $>$ & $>$ & $>$ & $>$ & $>$ & $>$ & $z$ \\
\hline & $\varepsilon Z Z / L G / S \exists Y / \forall$ & て00でてレ・৪レ & $>$ & $\varangle$ & $>$ & $>$ & $>$ & $\varangle$ & $\varangle$ & $z$ \\
\hline & 0SL/9G/S $\exists \mathrm{d} / \forall$ & เ00Zてレ゙6レ & $>$ & $\varangle$ & $>$ & $>$ & $>$ & $>$ & $\varangle$ & $z$ \\
\hline & $\mathrm{SLL/tG/S} \exists \mathrm{d} / \forall$ & 666เてレくL & $>$ & $\varangle$ & $>$ & $>$ & $>$ & $>$ & $\varangle$ & $z$ \\
\hline & GSL/EG/S $\exists Y / \forall$ & 866レ゙で60 & $>$ & $\varangle$ & $>$ & $>$ & $>$ & $>$ & $\varangle$ & $z$ \\
\hline & $9 \varepsilon\llcorner/ 乙 S / S \exists ४ / \forall$ & ட66เてレ゙レ & $>$ & $\varangle$ & $>$ & $>$ & $>$ & $>$ & $z$ & $z$ \\
\hline & $\varepsilon \varepsilon\llcorner/ L \nabla / S \exists y / \forall$ & 986レ゙てレ゙ナ0 & $>$ & & $>$ & $>$ & $\gtreqless$ & $>$ & z & $z$ \\
\hline 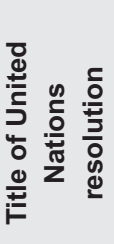 & 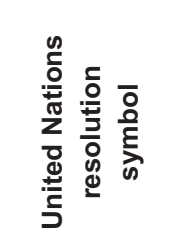 & 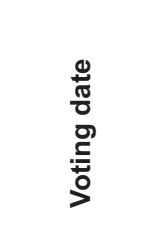 & 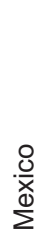 & 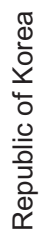 & 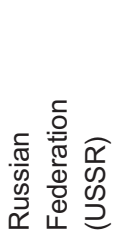 & $\begin{array}{l}\frac{\pi}{0} \\
\frac{\pi}{0} \\
\frac{\pi}{2} \\
\frac{0}{0} \\
\frac{\pi}{0} \\
\omega\end{array}$ & 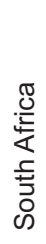 & 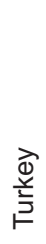 & 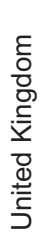 & 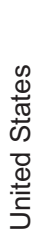 \\
\hline
\end{tabular}




\begin{tabular}{|c|c|c|c|c|c|c|c|}
\hline \multirow{19}{*}{ 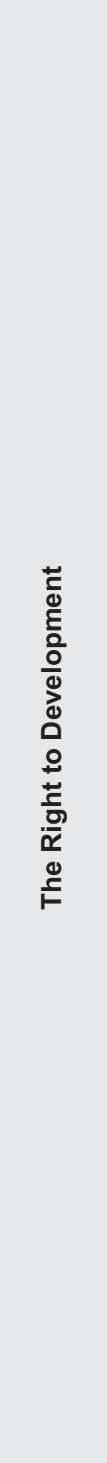 } & GsL/0L/S $\exists y / \forall$ & SLOZZL'LL & ஜூ & $\stackrel{\infty}{+}$ & 6 & $m$ & 0 \\
\hline & L৪L/69/S $\exists y / \forall$ & カレズてレ゙レ & ஜூ & م & 10 & $\stackrel{\leftrightarrow}{N}$ & 0 \\
\hline & 8SL/89/S $\exists Y / \forall$ & ยレ૦でてレ゙L & $\stackrel{m}{\sigma}$ & 足 & ४ & $\stackrel{\sim}{\sim}$ & $m$ \\
\hline & $L \angle L / \angle 9 / S \exists Y / \forall$ & てレでてレ゚て & $\stackrel{m}{\sigma}$ & 官 & ४ & $\stackrel{\sim}{\sim}$ & $\wedge$ \\
\hline & SSL/99/S $\exists Y / \forall$ & レーでてレ6レ & $\stackrel{m}{\sigma}$ & 点 & 6 & 尺 & $\nabla$ \\
\hline & $6 \mathrm{LZ/S9/S} \exists \mathrm{U} / \forall$ & OレOZ゙ートレ & ๙ั & $\stackrel{m}{m}$ & ম & $\stackrel{\infty}{\sim}$ & $\wedge$ \\
\hline & ZLL/†9/S $\exists \mathrm{U} / \forall$ & 600Z゙Zレ・8レ & ๙ั & $\stackrel{m}{\dddot{m}}$ & N & ஜ & 0 \\
\hline & 8LL/ع9/S $\exists y / \forall$ & 800Z゙レ・8ト & ๙ั & 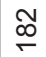 & t & $N$ & $\nabla$ \\
\hline & I9L/Z9/S $\exists y / \forall$ & LOOZ'Zレ'8L & ๙ั & $\stackrel{\varphi}{\stackrel{m}{\sigma}}$ & ח & 0 & $m$ \\
\hline & $69 \mathrm{~L} / \mathrm{L} 9 / \mathrm{S} \exists \mathrm{d} / \forall$ & 900Z゙てレ6ト & ๙ั & mे & ח & 0 & م \\
\hline & $\angle G L / 09 / S \exists Y / \forall$ & ง00Z゙レ・9レ & бั & $\stackrel{2}{N}$ & $\sim$ & 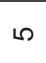 & $\cong$ \\
\hline & s৪L/6ৎ/S $\exists \mathrm{d} / \forall$ & †00Z゙レ・0Z & চூ & $\stackrel{\infty}{\infty}$ & $\sim$ & $\checkmark$ & $\checkmark$ \\
\hline & ZLL/8G/S $\exists d / \forall$ & 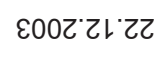 & б & $\stackrel{m}{\stackrel{n}{r}}$ & $m$ & 10 & 으 \\
\hline & $\varepsilon Z Z / L S / S \exists Y / \forall$ & Z00Z゙レ・8レ & Бَ & $\stackrel{m}{m}$ & $\theta$ & 守 & $\wedge$ \\
\hline & 0SL/9G/S $\exists \mathrm{d} / \forall$ & เOOZ゙レ゙6レ & $\stackrel{\infty}{\infty}$ & $\stackrel{m}{N}$ & $\theta$ & 寸 & $\stackrel{\infty}{\leftarrow}$ \\
\hline & $\mathrm{G} L \mathrm{~L} / \downarrow \mathrm{G} / \mathrm{S} \exists \mathrm{d} / \forall$ & 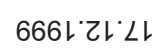 & $\stackrel{\infty}{\infty}$ & $\stackrel{9}{\leftarrow}$ & 으 & $\stackrel{\infty}{\infty}$ & $\bar{N}$ \\
\hline & SGL/દG/S $\exists$ / $\forall$ & 866レ゙てレ60 & $\stackrel{\infty}{\infty}$ & $\stackrel{\sim}{N}$ & - & $\stackrel{\mathcal{Y}}{\mathcal{T}}$ & $\approx$ \\
\hline & 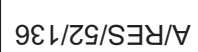 & ட66レ`Zレ゙レ & $\stackrel{\infty}{\infty}$ & 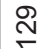 & $\cong$ & लै & $\stackrel{\sim}{\sim}$ \\
\hline & $\varepsilon \varepsilon\llcorner/ L / / S \exists y / \forall$ & 986レ゙てレ゙ち0 & 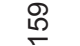 & $\stackrel{m}{m}$ & $\mp$ & $\stackrel{\simeq}{\longleftarrow}$ & $m$ \\
\hline 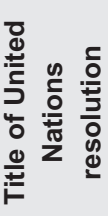 & 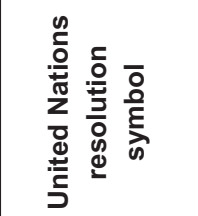 & 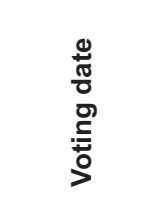 & 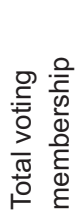 & $\stackrel{\mathscr{d}}{\nu}$ & 은 & 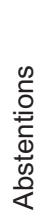 & 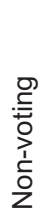 \\
\hline
\end{tabular}


Mr. Lavrov mentioned that the Russian Federation welcomed the adoption of the new 2030 Agenda for Development and was ready to support the successful implementation of this programme at all levels. He went on to say that poverty eradication was a key objective of the country's IDA policy (Goal 1) and stressed its development assistance was invariably aimed at solving the most pressing challenges faced by countries in need. In those efforts, the country was neither trying to lecture its partners on how they should build their lives, nor impose political models and values (against politicization of development agenda, Goal 16). The Russian Federation actively uses the capacities offered by the United Nations development system organizations and humanitarian agencies "...that provide assistance without conditions and in a politically unbiased manner".

Debt relief is an effective tool of poverty eradication. Under the Heavily Indebted Poor Countries (HIPC) Initiative, the Russian Federation has written off more than US $\$ 20$ billion of debt owed by African countries alone. The country also contributes to reducing the debt burden of the poorest countries beyond the Initiative through debt-for-aid swaps (Goal 17). It has been funding and implementing aid projects on education (Goal 4), health care (Goal 3), energy (Goal 7), food security (Goal 2) and infrastructure (Goal 9). Despite the challenging economic environment, the Russian Federation remains a responsible and reliable partner to developing countries in addressing the most pressing challenges confronting its citizens, such as the spread of HIVIAIDS, tuberculosis and malaria, maternal, infant and child mortality issues or the Ebola outbreak (Goal 3). ODA extended by the Russian Federation is increasing. In 2014, it rose by more than 20 per cent and the overall amount of ODA from the Russian Federation, in accordance with OECD methodology, surpassed $\$ 875$ million (Goal 17).

Mr. Lavrov has stressed, that "a new socioeconomic agenda should ensure the indivisibility of sustainable development". The Russian Federation stands for creating a more equitable global economic order and ensuring better governance for global development. It is especially important to ensure fair trade (Goal 10; Goal 17) and enhanced access to cutting-edge technologies (Goal 17). According to the foreign minister, the Russian Federation calls "... for more consistent efforts to reform the governance structures, in particular the IMF and the World Bank, by strengthening the developing countries' positions (Goal 10; Goal 16). We stand for a more efficient interaction between the General Assembly and ECOSOC [Economic and Social Council] and the Bretton Woods institutions and the WTO [World Trade Organization]".

The Russian Federation remains committed to consolidating regional cooperation, including integration in the Eurasian space. While developing a Eurasian Economic Union, the Russian Federation always stands for the harmonization of the 
various integration mechanisms both in the East and in the West. Unilateral coercive measures that are imposed in violation of the United Nations Charter are in direct contradiction with the achievement of Sustainable Development Goals. This fully applies to lifting the embargo against Cuba, as well as to other sanctions which have bypassed the United Nations Security Council.

The Russian Federation is well known for its debt relief programmes and socioeconomic programmes. However, the country also pays special attention to climate issues, considering that a solution to the climate change problem is one of the key preconditions for achieving sustainable development. The Russian Federation is the global leader in the cumulative reduction of greenhouse gas emissions and compensates for the increases in emissions in other countries and regions of the world. The country has gone beyond its commitments under the Kyoto Protocol by reducing emissions by 31 per cent below 1990 levels (Goal 13). The country also highlights the role of its boreal forests, which absorb about 600 million tons of carbon dioxide per year. The country will push for including the forest factor in the framework of a new climate agreement and also consider complementing the efforts under the aegis of the United Nations Forum on Forests with practical actions within some form of a United Nations centre for planning, protection and the rehabilitation of forests (Goal 15). Although the Russian Federation was not a member of any of the groups set up during the Open Working Group consultations and made only a few statements on the Sustainable Development Goals, the above-mentioned information provided by Mr. Lavrov offers the possibility to evaluate position of the Russian Federation towards most of the Sustainable Development Goals.

\section{CONCLUSION}

An analysis of the statements of donor countries and recipient countries shows the heterogeneity of their positions, as well as the divergence of the views on ways to achieve the Sustainable Development Goals. The position of donors from the BRICS countries, including the Russian Federation, on a number of the goals is close to that of aid recipient countries. However, despite the differences of opinion between donor countries and recipient countries, the consultative process for the elaboration of Sustainable Development Goals has shown good results. This positive start gives a good perspective for further progressive work of all participating countries and the possibility of progress towards the achievement of the Sustainable Development Goals. 


\section{REFERENCES}

Bartenev, Vladmir (2015). Vklyuchenie problem mira, bezopasnosti i kachestva upravleniya $v$ global'nuyu povestku dnya ustoichivogo razvitiya na period do 2030 g.: analiz khoda i soderzhaniya mezhdunarodnykh peregovorov (Inclusion of peace, security, and governance targets in the Global Sustainable Development Agenda to 2030: decomposing intergovernmental negotiations). Vestnik mezhdunarodnykh organizatsii (International Organizations Research Journal), vol. 10, No. 3. pp. 7-32 (In Russian).

Bhattacharya, Debapriya, Towfiqul Islam Khan, and Umme Salma (2014). A commentary on the final outcome document of the Open Working Group on SDGs. SAIS Review of International Affairs, vol. 34, No. 2, pp. 165-177.

Burkett, Paul, and Martin Hart-Landsberg (2003). A critique of "catch-up" theories of development. Journal of Contemporary Asia, vol. 33, No. 2, pp. 147-171.

Degterev, Denis (2013a). Rossiiskaya Federatsiya kak novyi mezhdunarodnyi donor: dilemmy identichnosti (Russian Federation as a new international donor: identity's dilemmas). Vestnik mezhdunarodnykh organizatsii (International Organizations Research Journal), vol. 8, No. 2, pp. 69-85 (In Russian).

(2013b). Sodeistvie mezhdunarodnomu razvitiyu: evolyutsiya mezhdunarodno-pravovykh rezhimov i effektivnost' vneshnei pomoshchi (International development assistance: the evolution of international legal regimes and aid effectiveness). Moscow: Lenand (In Russian).

Nelson, Travis (2012). Determinants of disaster aid: donor interest or recipient need? Global Change, Peace \& Security, vol. 24, No. 1, pp. 109-126.

Oldfield, Jonathan, and Denis James Barrington Shaw (2002). Revisiting sustainable development: Russian cultural and scientific traditions and the concept of sustainable development. Area, vol. 4, No. 4, pp. 391-400.

Open Working Group of the General Assembly (2014). Report on Sustainable Development Goals. Available from www.un.org/ga/search/view_doc.asp?symbol=A/68/970.

Ryu, Yongwook, and Maria Ortuoste (2014). Democratization, regional integration, and human rights: the case of the ASEAN intergovernmental commission on human rights. The Pacific Review, vol. 27, No. 2, pp. 357-382.

Sarkar, Ramu (2009). International Development Law. Rule of Law, Human Rights, and Global Finance. Oxford, U.K.: Oxford University Press.

Vandenhole, Wouter, and Paul Gready (2014). Failures and successes of human rights-based approaches to development: towards a change perspective. Nordic Journal of Human Rights, vol. 32, No. 4, pp. 291-311. 


\section{ANNEX \\ List of the Sustainable Development Goals}

\begin{tabular}{|c|c|c|}
\hline Goal & Short name & Full name \\
\hline 1 & No poverty & End poverty in all its forms everywhere \\
\hline 2 & Zero hunger & $\begin{array}{l}\text { End hunger, achieve food security and improved nutrition } \\
\text { and promote sustainable agriculture }\end{array}$ \\
\hline 3 & Good health and well-being & $\begin{array}{l}\text { Ensure healthy lives and promote well-being for all at all } \\
\text { ages }\end{array}$ \\
\hline 4 & Quality education & $\begin{array}{l}\text { Ensure inclusive and equitable quality education and } \\
\text { promote lifelong learning opportunities for all }\end{array}$ \\
\hline 5 & Gender equality & $\begin{array}{l}\text { Achieve gender equality and empower all women and } \\
\text { girls }\end{array}$ \\
\hline 6 & Clean water and sanitation & $\begin{array}{l}\text { Ensure availability and sustainable management of water } \\
\text { and sanitation for all }\end{array}$ \\
\hline 7 & Affordable and clean energy & $\begin{array}{l}\text { Ensure access to affordable, reliable, sustainable and } \\
\text { modern energy for all }\end{array}$ \\
\hline 8 & $\begin{array}{l}\text { Decent work and economic } \\
\text { growth }\end{array}$ & $\begin{array}{l}\text { Promote sustained, inclusive and sustainable economic } \\
\text { growth, full and productive employment and decent work } \\
\text { for all }\end{array}$ \\
\hline 9 & $\begin{array}{l}\text { Industry, innovation and } \\
\text { infrastructure }\end{array}$ & $\begin{array}{l}\text { Build resilient infrastructure, promote inclusive and } \\
\text { sustainable industrialization and foster innovation }\end{array}$ \\
\hline 10 & Reduced inequalities & Reduce income inequality within and among countries \\
\hline 11 & $\begin{array}{l}\text { Sustainable cities and } \\
\text { communities }\end{array}$ & $\begin{array}{l}\text { Make cities and human settlements inclusive, safe, } \\
\text { resilient and sustainable }\end{array}$ \\
\hline 12 & $\begin{array}{l}\text { Responsible consumption } \\
\text { and production }\end{array}$ & Ensure sustainable consumption and production patterns \\
\hline 13 & Climate action & $\begin{array}{l}\text { Take urgent action to combat climate change and its } \\
\text { impacts }\end{array}$ \\
\hline 14 & Life below water & $\begin{array}{l}\text { Conserve and sustainably use the oceans, seas and } \\
\text { marine resources for sustainable development }\end{array}$ \\
\hline 15 & Life on land & $\begin{array}{l}\text { Protect, restore and promote sustainable use of } \\
\text { terrestrial ecosystems, sustainably manage forests, } \\
\text { combat desertification, and halt and reverse land } \\
\text { degradation and halt biodiversity loss }\end{array}$ \\
\hline
\end{tabular}




\section{ANNEX (continued)}

\section{List of the Sustainable Development Goals}

\begin{tabular}{cll}
\hline Goal & \multicolumn{1}{c}{ Short name } & \multicolumn{1}{c}{ Full name } \\
\hline 16 & $\begin{array}{l}\text { Peace, justice and strong } \\
\text { institutions }\end{array}$ & $\begin{array}{l}\text { Promote peaceful and inclusive societies for sustainable } \\
\text { development, provide access to justice for all and build } \\
\text { effective, accountable and inclusive institutions at all } \\
\text { levels }\end{array}$ \\
17 & Partnerships for the goals & $\begin{array}{l}\text { Strengthen the means of implementation and revitalize the } \\
\text { Global Partnership for Sustainable Development }\end{array}$ \\
\hline
\end{tabular}

Source: A/RES/70/1 - Transforming our world: the 2030 Agenda for Sustainable Development. 